OPEN ACCESS

Edited by:

Fahmeed Hyder,

Yale University, United States

Reviewed by: Andre Strydom,

University College London,

United Kingdom

Jean Chen,

University of Toronto, Canada

*Correspondence:

Elizabeth Head

elizabeth.head@uky.edu

Received: 03 April 2018 Accepted: 06 June 2018

Published: 21 June 2018

Citation:

Head E, Powell DK and Schmitt FA

(2018) Metabolic and Vascular

Imaging Biomarkers in Down

Syndrome Provide Unique Insights

Into Brain Aging and Alzheimer

Disease Pathogenesis.

Front. Aging Neurosci. 10:191

doi: 10.3389/fnagi.2018.00191

\section{Metabolic and Vascular Imaging Biomarkers in Down Syndrome Provide Unique Insights Into Brain Aging and Alzheimer Disease Pathogenesis}

\author{
Elizabeth Head ${ }^{1 *}$, David K. Powell ${ }^{2}$ and Frederick A. Schmitt ${ }^{3}$ \\ 1 Department of Pharmacology \& Nutritional Sciences, Sanders Brown Center on Aging, University of Kentucky, Lexington, \\ KY, United States, ${ }^{2}$ Magnetic Resonance Imaging and Spectroscopy Center, Sanders Brown Center on Aging, University of \\ Kentucky, Lexington, KY, United States, ${ }^{3}$ Department of Neurology, Sanders Brown Center on Aging, University of Kentucky, \\ Lexington, KY, United States
}

People with Down syndrome (DS) are at high risk for developing Alzheimer disease (AD). Neuropathology consistent with $A D$ is present by 40 years of age and dementia may develop up to a decade later. In this review, we describe metabolic and vascular neuroimaging studies in DS that suggest these functional changes are a key feature of aging, linked to cognitive decline and AD in this vulnerable cohort. FDG-PET imaging in DS suggests systematic reductions in glucose metabolism in posterior cingulate and parietotemporal cortex. Magentic resonance spectroscopy studies show consistent decreases in neuronal health and increased myoinositol, suggesting inflammation. There are few vascular imaging studies in DS suggesting a gap in our knowledge. Future studies would benefit from longitudinal measures and combining various imaging approaches to identify early signs of dementia in DS that may be amenable to intervention.

Keywords: dementia, FDG-PET, hypometabolism, hypermetabolism, myoinositol, MR spectroscopy, T2*, trisomy 21

\section{INTRODUCTION}

The life expectancy of people with Down syndrome (DS) continues to increase due to improved health care and management of co-occurring illnesses (Bittles and Glasson, 2004). Consequently there are more people with DS and the population has grown from 49,923 in 1950 to 206, 336 in 2010 (de Graaf et al., 2017). However, mortality rate is higher in people with DS in older ages relative to the general population ( $\mathrm{Ng}$ et al., 2017) and further, some deaths such as those due to respiratory disorders and epilepsy may be amenable to medical intervention (Hosking et al., 2016). As with the general population, the risk of developing health-related problems increases as people with DS get older. In particular, people with DS are at a high risk of developing cognitive impairment and clinical dementia after the age of 50 years (Zigman et al., 1996; Sinai et al., 2018). Virtually all adults with DS develop the neuropathology for a brain-based Alzheimer disease (AD) diagnosis by the age of 40 years (reviewed in Head et al., 2016). This is thought to be due to the lifelong overexpression of the APP gene on chromosome 21 leading to early onset and rapid accumulation of beta-amyloid (A $\beta$ ) with age (Head et al., 2016). Thus, by studying individuals with DS across the lifespan it is possible 
to identify early biomarkers of $\mathrm{AD}$ pathogenesis that may not be feasible in the general population as the age of onset of $\mathrm{AD}$ varies tremendously (e.g., 50-over 100 years). As will be discussed later in this review, cerebrovascular pathology may help to accelerate $\mathrm{AD}$ in $\mathrm{DS}$ and be an important contributor to dementia. Interestingly, a subset of adults with DS never develops dementia even in the presence of this $\mathrm{AD}$ pathology (Franceschi et al., 1990; Schupf and Sergievsky, 2002; Head et al., 2012a,b).

Neuroimaging studies help us detect structural, connectivity, activity, neurochemical, and vascular/metabolic functional changes with age and with the development of $\mathrm{AD}$. As the development of $\mathrm{AD}$ neuropathology in DS is strongly agedependent, we can learn about early changes associated with the progression of $\mathrm{AD}$ through neuroimaging studies in DS (Neale et al., 2018). These studies not only help us understand aging and $\mathrm{AD}$ in people with DS but can translate to our understanding of $\mathrm{AD}$ in the general population. For example, Jack and Holtzman (2013) proposed a hypothetical series of biomarker events including neuroimaging outcomes that may occur prior to changes in cognition and be predictive of decline in the general population. For example, Jack and colleagues suggest that $\mathrm{A} \beta$ can be detected prior to brain structure changes, which in turn are detectable prior to mild cognitive impairment and dementia. A similar series of biomarker events can be hypothetically applied for people with DS but using age as opposed to the clinical disease stage as the time axis. Whereas in the general population, biomarker changes reflecting progressive $\mathrm{AD}$ are plotted as a function of the cognitive continiuum, in DS we can use age as a representative to $\mathrm{AD}$ pathogenesis. It is clear from this hypothetical model that neuroimaging can provide early markers of dementia-associated brain changes and the inclusion of vascular or metabolic imaging may play an important role by providing even earlier information regarding $\mathrm{AD}$ pathogenesis.

\section{METABOLIC IMAGING BIOMARKERS-FDG-PET}

Metabolic imaging using positron emission tomography (PET) has consistently shown reductions in glucose utilization in vulnerable brain regions in sporadic AD (Silverman and Phelps, 2001). In particular, the precuneus, posterior cingulate cortex and posterior parietotemporal lobes may be the earliest site of reduced glucose metabolism (FDG-PET) prior to onset of symptoms (Minoshima et al., 1997). In AD, the extent of cerebral metabolic rate of glucose from FDG-PET studies (CMRglu) is correlated with the severity of dementia (Minoshima et al., 1997). As $\mathrm{AD}$ progresses, more brain regions show declines in CMRglu such as the frontal cortex. CMRglu from FDG-PET can also predict AD neuropathology with $84-93 \%$ sensitivity and $73 \%$ specificity (Silverman et al., 2001; Jagust et al., 2007).

There are relatively few FDG-PET studies in DS with the majority being acquired under resting conditions (Table 1 summarizes studies since 1983). However the results of these studies have been relatively consistent. First, younger individuals with DS (without dementia) show increased glucose metabolism (Schwartz et al., 1983; Cutler, 1986;
Azari et al., 1994a; Haier et al., 2003, 2008; Lengyel et al., 2006; Matthews et al., 2016) relative to age matched controls in all but one study (Schapiro et al., 1992b). The regions that show hypermetabolism include the prefrontal cortex, sensorimotor cortex, thalamus, inferior temporal/entorhinal cortex. Interestingly, increased glucose metabolic rate is associated with decreased gray matter volume in the temporal cortex including the parahippocampus/hippocampus suggesting that hypermetabolism is a compensatory response (Haier et al., 2008). Indeed, autopsy studies of the same brain region in a case series of DS shows evidence of neuronal sprouting positive for tau phosphorylation suggesting a mechanistic basis for increased glucose metabolism in middle age (Head et al., 2003). Other molecular events may also underlie this phenomenon (reviewed in Head et al., 2007).

In contrast, older individuals with DS and particularly those with dementia show hypometabolism in multiple studies (Schwartz et al., 1983; Cutler, 1986; Schapiro et al., 1992a; Azari et al., 1994a,b; Rafii et al., 2015; Sabbagh et al., 2015; Matthews et al., 2016). Brain regions that appear to be systematically affected under either resting or active conditions include the posterior cingulate cortex, hippocampus, parietal and temporal cortex consistent with reports in sporadic AD (Minoshima et al., 1997; Pietrini et al., 1997; Silverman and Phelps, 2001). Further, in a 45 year old female with mosaic/translation DS with clinical signs of early dementia, a pattern of hypometabolism similar to that of sporadic AD was observed (Schapiro et al., 1992a).

Reduced glucose metabolism in older adults with DS and dementia is associated with decreased cortical volumes (Matthews et al., 2016), increased amyloid binding with florbetapir (Matthews et al., 2016) and increased tau binding using AV-1451 (Rafii et al., 2017). Some studies report associations between cognition and glucose metabolism (Haier et al., 2008; Sabbagh et al., 2015; Matthews et al., 2016) but not all (Rafii et al., 2015), with variable results likely due to smaller sample sizes. In one of the only longitudinal studies that was found, Dani and colleagues reported stable glucose metabolic rates over a 7 year period of time unless clinical dementia had evolved (occurred in one person with DS) leading to rapid glucose metabolic decline in parietal and temporal cortices (Dani et al., 1996).

Reductions in glucose metabolism may lead to or reflect neuronal loss, synapse loss, and/or mitochondrial dysfunction. Given that all these events are thought to occur with age and dementia in DS (Head et al., 2016), PET imaging can provide useful information with respect to brain function but there is a clear need for more longitudinal studies that includes measures of cognition. It is also notable that despite the posterior cingulate cortex being an early site of glucose metabolic losses, there are few studies of $\mathrm{AD}$ neuropathology in this region in DS. The use of FDG-PET to capture information about metabolism requires the use of intravenous injections of radioactive ligands. This procedure may be problematic for some participants, their families and particularly for those with dementia. However, as an outcome measure that may reflect a rapid response to treatment that is targeting metabolism, FDG-PET has utility. In future, similar outcomes reflecting metabolic changes such as blood flow, 
TABLE 1 | Summary of FDG-PET studies in DS (since 1983).

\begin{tabular}{|c|c|c|c|c|c|c|}
\hline Authors & Date & $\begin{array}{l}\text { Resting } \\
\text { or active }\end{array}$ & Cohort & Clinical data & Outcome & References \\
\hline $\begin{array}{l}\text { Schwartz } \\
\text { et al. }\end{array}$ & 1983 & Resting & $\begin{array}{l}n=4 \text { young DS } 19-27 \text { years and } \\
n=1 \text { aged DS } 51 \text { years, } n=10 \\
\text { young controls } 21-33 \text { years and } \\
n=8 \text { aged controls } 45-55 \text { years }\end{array}$ & None & $\begin{array}{l}\text { Increased glucose metabolic rate in } \\
\text { multiple brain regions in young DS } \\
\text { relative to age matched controls } \\
\text { whereas the } 51 \text { year old showed } \\
\text { reduced metabolic rate to young DS } \\
\text { controls (but not to old controls). }\end{array}$ & $\begin{array}{l}\text { Schwartz } \\
\text { et al., } 1983\end{array}$ \\
\hline $\begin{array}{l}\text { Schapiro } \\
\text { et al. }\end{array}$ & 1988 & Resting & $\begin{array}{l}n=1 \text { DS } 47 \text { years with autopsy } \\
\text { confirmed AD, } n=13 \\
\text { non-demented DS, } 19-33 \text { years) }\end{array}$ & $\begin{array}{l}\text { General intelligence, } \\
\text { visuospatial ability, } \\
\text { language and memory }\end{array}$ & $\begin{array}{l}\text { Glucose metabolism was } 28 \% \text { less in } \\
\text { the demented DS case involving the } \\
\text { parietal and temporal cortex. }\end{array}$ & $\begin{array}{l}\text { Schapiro } \\
\text { et al., } 1988\end{array}$ \\
\hline Horwitz et al. & 1990 & Resting & $\begin{array}{l}n=14 \mathrm{DS}<34 \text { years vs. } n=24 \\
\text { controls }\end{array}$ & None & $\begin{array}{l}\text { The correlation between regional } \\
\text { rates of glucose metabolism in DS } \\
\text { was large and negative for the inferior } \\
\text { frontal gyrus including Broca's area } \\
\text { whereas in controls this association } \\
\text { was positive. }\end{array}$ & $\begin{array}{l}\text { Horwitz et al., } \\
1990\end{array}$ \\
\hline $\begin{array}{l}\text { Schapiro } \\
\text { et al. }\end{array}$ & 1992 & Resting & $\begin{array}{l}n=20 \text { DS } 19-34 \text { years and } 9 \\
\text { older DS, 45-63 years. Controls } \\
\text { were } n=1322=39 \text { years. }\end{array}$ & $\begin{array}{l}\text { Stanford-Binet, PPVT, } \\
\text { Digit Span, Block } \\
\text { Tapping Span and } \\
\text { Object Pointing Span, } \\
\text { Memory for Object } \\
\text { subtest from DSMSE } \\
\text { and recognition } \\
\text { memory for designs, } \\
\text { grammatic closure and } \\
\text { manual expression, } \\
\text { Hiskey Nebraska Block } \\
\text { Pattery Subtest, } \\
\text { WISC-R Block design }\end{array}$ & $\begin{array}{l}\text { No difference in glucose metabolism } \\
\text { found between young DS and young } \\
\text { controls. DS with dementia had } \\
\text { hypometabolism in association } \\
\text { cortices (parietal and lateral temporal) } \\
\text { and primary neocortex (sensorimotor } \\
\text { and occipital). Mosaic/translation } \\
\text { person with DS ( } 45 \text { years) with mild } \\
\text { dementia showed reduced temporal } \\
\text { glucose metabolism. }\end{array}$ & $\begin{array}{l}\text { Schapiro } \\
\text { et al., 1992a }\end{array}$ \\
\hline Azari et al. & 1994 & Resting & $\begin{array}{l}n=15 \text { Young DS, } n=10 \text { older } \\
\text { DS without dementia, } n=4 \text { DS } \\
\text { with dementia and } n=15 \text { young } \\
\text { controls }\end{array}$ & Stanford-Binet, DSMSE & $\begin{array}{l}\text { All DS with dementia and some of the } \\
\text { DS without dementia scans appeared } \\
\text { similar to that of AD patterns. }\end{array}$ & $\begin{array}{l}\text { Azari et al., } \\
1994 a\end{array}$ \\
\hline Dani et al. & 1996 & Resting & $\begin{array}{l}n=12 \text { non-demented DS } 31-59 \\
\text { years, longitudinal evaluation }-n \\
=2 \text { ( } 49,50 \text { years) became } \\
\text { demented }\end{array}$ & DSMSE & $\begin{array}{l}\text { People with DS who were } \\
\text { non-demented did not show changes } \\
\text { in glucose metabolism over } 7 \text { years. } \\
\text { Two people developed dementia after } \\
7 \text { years and showed a rapid decline in } \\
\text { glucose metabolism in parietal and } \\
\text { temporal regions. }\end{array}$ & $\begin{array}{l}\text { Dani et al., } \\
1996\end{array}$ \\
\hline Pietrini et al. & 1997 & $\begin{array}{l}\text { Resting } \\
\text { and } \\
\text { audiovisual } \\
\text { stimulation }\end{array}$ & $\begin{array}{l}n=8 \text { DS } 32-38 \text { years and } n=8 \\
\text { DS 43-61 years }\end{array}$ & $\begin{array}{l}\text { Stanford-Binet } \\
\text { Intelligence Scale, } \\
\text { DSMSE, PPVT }\end{array}$ & $\begin{array}{l}\text { At rest, no differences in glucose } \\
\text { metabolism were observed. During } \\
\text { stimulation, older subjects with DS } \\
\text { showed reduced glucose metabolic } \\
\text { rates in parietal and temporal cortex. }\end{array}$ & $\begin{array}{l}\text { Pietrini et al., } \\
1997\end{array}$ \\
\hline
\end{tabular}


TABLE 1 | Continued

\begin{tabular}{|c|c|c|c|c|c|c|}
\hline Authors & Date & $\begin{array}{l}\text { Resting } \\
\text { or active }\end{array}$ & Cohort & Clinical data & Outcome & References \\
\hline Haier et al. & 2003 & $\begin{array}{l}\text { Continuous } \\
\text { performance } \\
\text { task }\end{array}$ & $\begin{array}{l}n=17 \text { DS (non-demented } \\
34-55 \text { years), } n-n=10 \\
\text { moderate } \mathrm{AD}, n=12 \text { young } \\
\text { controls, } n=12 \text { old controls) }\end{array}$ & $\begin{array}{l}\text { Wechsler Adult } \\
\text { Intelligence Scale III, } \\
\text { DSDS, DMR, MMSE } \\
\text { (for AD) }\end{array}$ & $\begin{array}{l}\text { DS and AD participants had lower } \\
\text { glucose metabolic rates relative to } \\
\text { each of their control groups in the } \\
\text { posterior cingulate. DS had higher } \\
\text { GMR in inferior temporal/entorhinal } \\
\text { cortex where AD subjects had lower } \\
\text { GMR. Non-demented people with DS } \\
\text { showed hypermetabolism as a } \\
\text { compensatory response. }\end{array}$ & $\begin{array}{l}\text { Haier et al., } \\
2003\end{array}$ \\
\hline Lengyel et al. & 2006 & Resting & $\begin{array}{l}n=11 \text { DS (5-24 years) and } n= \\
9 \text { control (4-24 years) }\end{array}$ & None & $\begin{array}{l}\text { Glucose metabolic rate was higher in } \\
\text { DS relative to controls in } 6 \text { regions: } \\
\text { left medial temporal gyrus, left } \\
\text { precentral and inferior frontal gyri, } \\
\text { anterior cingulate gyri. }\end{array}$ & $\begin{array}{l}\text { Lengyel et al., } \\
2006\end{array}$ \\
\hline Rafii et al. & 2015 & Resting & $\begin{array}{l}n=12 \text { non-demented DS } \\
\text { (30-60 years) }\end{array}$ & $\begin{array}{l}\text { CANTAB, RBANS, } \\
\text { VABS, Observer } \\
\text { Memory } \\
\text { Questionnaire-Parent } \\
\text { Form, Anxiety } \\
\text { Depression and Mood } \\
\text { Scale, Cambridge } \\
\text { Examination for Mental } \\
\text { Disorders of Older } \\
\text { People with Down's } \\
\text { syndrome and other } \\
\text { with Intellectual } \\
\text { Disability, Dalton } \\
\text { Dyspraxia scale, } \\
\text { Goodenough-Harris } \\
\text { Draw-A-Person Test }\end{array}$ & $\begin{array}{l}\text { People with DS over } 39 \text { years age of } \\
\text { showed consistent hypometabolism } \\
\text { by clinical read. No correlations with } \\
\text { cognition. }\end{array}$ & $\begin{array}{l}\text { Rafii et al., } \\
2015\end{array}$ \\
\hline $\begin{array}{l}\text { Sabbagh } \\
\text { et al. }\end{array}$ & 2015 & Resting & $\begin{array}{l}n=5 \mathrm{DS} \text { with AD, } 12 \\
\text { non-demented DS and } 9 \text { normal } \\
\text { controls }\end{array}$ & $\begin{array}{l}\text { DMR, MMSE, BPT, SIB } \\
\text { and VABS }\end{array}$ & $\begin{array}{l}\text { DS with AD showed hypometabolism } \\
\text { in posterior cingulate, lateral parietal, } \\
\text { and temporal and frontal regions. } \\
\text { Non-demented and demented DS } \\
\text { had lower glucose metabolic rates in } \\
\text { additional frontal regions compared } \\
\text { with controls. }\end{array}$ & $\begin{array}{l}\text { Sabbagh } \\
\text { et al., } 2015\end{array}$ \\
\hline $\begin{array}{l}\text { Matthews } \\
\text { et al. }\end{array}$ & 2016 & & $\begin{array}{l}n=12 \text { non-demented DS } \\
\text { (32-61 years), } n=12 \text { normal, } n \\
=12 \text { early } \mathrm{MCl}, n=12 \text { late } \mathrm{MCl}, \\
n=12 \mathrm{AD} \text { and } n=12 \text { and } \\
\text { controls from } \mathrm{ADNI}\end{array}$ & VABS & $\begin{array}{l}\text { Posterior cingulate cortex and } \\
\text { hippocampus showed } \\
\text { hypometabolism in DS relative to } \\
\text { controls. Lower glucose metabolic } \\
\text { rate was observed in regions showing } \\
\text { volumetric losses (mid cingulate, } \\
\text { anterior cingulate, paracentral lobule, } \\
\text { and hippocampus). Hypermetabolism } \\
\text { was observed with preserved volume } \\
\text { in the prefrontal cortex but reduced } \\
\text { volume in occipital cortex. Patterns of } \\
\text { glucose metabolism and volume } \\
\text { losses corresponded to amyloid } \\
\text { burden (florbetapir) and cognition. }\end{array}$ & $\begin{array}{l}\text { Matthews } \\
\text { et al., } 2016\end{array}$ \\
\hline
\end{tabular}




\begin{tabular}{|c|c|c|c|c|c|c|}
\hline Authors & Date & $\begin{array}{l}\text { Resting } \\
\text { or active }\end{array}$ & Cohort & Clinical data & Outcome & References \\
\hline Rafii et al. & 2017 & Resting & $\begin{array}{l}n=12 \text { non-demented DS 30-60 } \\
\text { years, } n=12 \text { normal older } \\
\text { adults, } n=12 \mathrm{AD}\end{array}$ & $\begin{array}{l}\text { CANTAB, RBANS, } \\
\text { VABS, Observer } \\
\text { Memory } \\
\text { Questionnaire-Parent } \\
\text { Form, Anxiety } \\
\text { Depression and Mood } \\
\text { Scale, Cambridge } \\
\text { Examination for Mental } \\
\text { Disorders of Older } \\
\text { People with Down's } \\
\text { syndrome and other } \\
\text { with Intellectual } \\
\text { Disability, Dalton } \\
\text { Dyspraxia scale, } \\
\text { Goodenough-Harris } \\
\text { Draw-A-Person Test }\end{array}$ & $\begin{array}{l}\text { Areas with lower glucose metabolic } \\
\text { rates were associated with tau } \\
\text { accumulation by PET (F-AV-1451). }\end{array}$ & $\begin{array}{l}\text { Rafii et al., } \\
2017\end{array}$ \\
\hline Lao et al. & 2018 & Resting & $\begin{array}{l}n=16 \text { non-demented DS (Avg } \\
\text { age } 35 \text { years -PiB negative), } n= \\
5 \text { non-demented DS (Avg age } 47 \\
\text { years-PiB positive), } n=3 \\
\text { demented DS (Avg age } 49 \text { years) }\end{array}$ & PPVT & $\begin{array}{l}\text { Glucose metabolism was reduced in } \\
\text { the parietal cortex with increased PiB } \\
\text { (amyloid) binding. Glucose } \\
\text { metabolism was negatively } \\
\text { associated with age (frontal, parietal, } \\
\text { and temporal cortex). No correlation } \\
\text { between striatal binding for PiB } \\
\text { (amyloid) and glucose metabolism. }\end{array}$ & $\begin{array}{l}\text { Lao et al., } \\
2018\end{array}$ \\
\hline
\end{tabular}

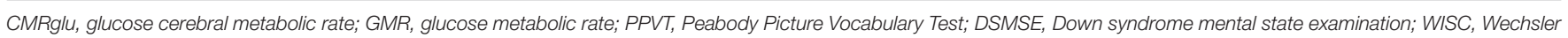

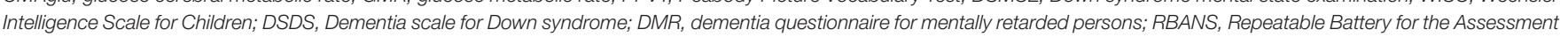

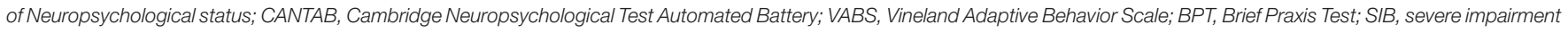
battery.

may be obtainable using relatively short MR protocols such as arterial spin labeling ( $7 \mathrm{~min}$ ). Further, as will be discussed next, magnetic resonance spectroscopy, which is also a relatively short protocol $(5 \mathrm{~min}$ ) that may be useful for a broader spectrum of participants can provide specific metabolic markers that could help dissect the different neuronal/glial pathways that signal onset of dementia.

\section{METABOLIC IMAGING BIOMARKERS-MRS}

Proton magnetic resonance spectroscopy $\left({ }^{1} \mathrm{H}-\mathrm{MRS}\right)$ has been widely used to characterize the neurochemistry of brain health and disease. In particular, the neuronal markers of $\mathrm{N}$ acetylaspartate (NAA) and glutamate-glutamine complex (Glx) decrease, and the glial marker of myo-inositol (MI) increases, both correlate with clinical variables in aging and AD (Parnetti et al., 1997; Lin and Rothman, 2014). It is thought that lower levels of NAA or Glx reflects neuronal loss or injury; neuroinflammation is associated with activated astrocytes and microglial cells leading to increased MI (Chang et al., 2013). The ratio of NAA to MI can also be used to distinguish non-demented from demented people (cf. Lin et al., 2005).

In DS, there have been several studies using MRS with assessments done for posterior cingulate cortex, hippocampus, frontal cortex, occipital cortex, and parietal cortex with comparisons to age matched controls (Table 2). Decreased NAA and increased MI is observed relatively consistently across studies in non-demented adults with DS compared with age matched non-DS controls (Shonk and Ross, 1995; Berry et al., 1999; Huang et al., 1999; Beacher et al., 2005; Lamar et al., 2011; Lin et al., 2016) with a few exceptions (Murata et al., 1993; Smigielska-Kuzia et al., 2010). Hippocampal Glx was not different in people with DS from controls (Tan et al., 2014). It may not be surprising that MI levels are generally higher in people with DS as the MI cotransporter (SLC5A3) gene is on chromosome 21 and is overexpressed in DS (Berry et al., 1995). Further, synaptojanin 1 (gene also on chromosome 21) can lead to increased gliosis (Herrera et al., 2009) and thus possibly, higher MI levels.

With age, older people with DS show higher MI and lower NAA than younger people with DS. MI was higher in the occipital and parietal cortex of older DS subjects relative to younger people with DS (Huang et al., 1999). In the hippocampus of older adults with dementia with DS, MI is also higher and NAA lower when compared to non-demented people with DS (Lamar et al., 2011) but Glx is unchanged (Tan et al., 2014). In the posterior cingulate cortex, MI was not significantly different in people with DS who were demented compared with those who were not demented, but NAA was significantly decreased (Lin et al., 2016). However, there is a case report of an individual with DS who was demented showing higher MI and lower NAA relative to non-demented DS individuals (Shonk and Ross, 1995). Further increases in MI reported in some studies with aging and dementia may reflect 
TABLE 2 | Summary of MRS studies in DS (since 1993).

\begin{tabular}{|c|c|c|c|c|c|c|}
\hline Authors & Date & Brain Region & Cohort & Clinical data & Outcome & References \\
\hline Murata et al. & 1993 & $\begin{array}{l}\text { white matter } \\
\text { around the } \\
\text { anterior horn of } \\
\text { the lateral ventricle } \\
\text { of frontal cortex }\end{array}$ & $\begin{array}{l}n=18 \text { DS } 20-40 \text { years, } n \\
=15 \text { controls (avg age } 35.8 \\
\text { years) }\end{array}$ & $\begin{array}{l}\text { Koh's } \\
\text { Block-Design Test, } \\
\text { Goodenough's } \\
\text { Draw a Man Test }\end{array}$ & $\begin{array}{l}\text { No differences in NAA noted across } \\
\text { the groups nor as a function of age. } \\
\text { MI was not analyzed. Note, many of } \\
\text { these DS participants were } \\
\text { institutionalized and controls were } \\
\text { physicians and staff members. Two } \\
\text { people with DS were mosaic. }\end{array}$ & Murata et al., 1993 \\
\hline Shonk \& Ross & 1995 & $\mathrm{~N} / \mathrm{A}$ & $\begin{array}{l}n=23 \text { non-demented DS } \\
\text { (age unknown), } n=1 \\
\text { demented DS (age } \\
\text { unknown) }\end{array}$ & Unknown & $\begin{array}{l}\text { MI was elevated in non-demented } \\
\text { people with DS relative to controls } \\
\text { and further elevated in DS with } \\
\text { dementia. NAA was decreased in the } \\
\text { DS with dementia participant. }\end{array}$ & $\begin{array}{l}\text { Shonk and Ross, } \\
1995\end{array}$ \\
\hline Huang et al. & 1999 & $\begin{array}{l}\text { parietal and } \\
\text { occipital cortex }\end{array}$ & $\begin{array}{l}n=8 \text { young DS } 28-39 \\
\text { years, } n-11 \text { non-demented } \\
\text { older DS } 42-62 \text { years, } n= \\
8 \text { young controls } 22-39 \\
\text { years and } n=9 \text { old controls } \\
40-64 \text { years }\end{array}$ & None & $\begin{array}{l}\text { MI was } 50 \% \text { higher in occipital and } \\
\text { parietal cortex of adults with DS } \\
\text { relative to controls. Older DS subjects } \\
\text { had higher MI than younger DS } \\
\text { subjects. NAA was lower in older DS } \\
\text { and controls relative to younger } \\
\text { controls but not exacerbated in DS. }\end{array}$ & Huang et al., 1999 \\
\hline Berry et al. & 1999 & corpus striatum & $\begin{array}{l}n=14,1.2-13.6 \text { years DS } \\
\text { and } n-131.3-11.7 \text { year old } \\
\text { controls }\end{array}$ & None & $\begin{array}{l}\text { MI was significantly higher (28\%) in } \\
\text { basal ganglia of DS relative to } \\
\text { controls. Choline containing } \\
\text { compounds were significantly lower in } \\
\text { DS relative to controls. }\end{array}$ & Berry et al., 1999 \\
\hline Beacher et al. & 2005 & Hippocampus & $\begin{array}{l}n=38,18-66 \text { years } \\
\text { non-demented DS and } n= \\
42,19-66 \text { controls }\end{array}$ & CAMCOG & $\begin{array}{l}\text { Hippocampal MI was higher in DS } \\
\text { than controls. In DS, hippocampal MI } \\
\text { correlated with cognition. }\end{array}$ & $\begin{array}{l}\text { Beacher et al., } \\
2005\end{array}$ \\
\hline $\begin{array}{l}\text { Smigielska-Kuzia } \\
\text { et al. }\end{array}$ & 2007 & Frontal cortex & $\begin{array}{l}n=14 \text { non-demented DS } \\
7-17 \text { years, } n=20 \text { controls }\end{array}$ & None & $\begin{array}{l}\text { Signficantly decreased Glx and NAA } \\
\text { observed in DS relative to controls. }\end{array}$ & $\begin{array}{l}\text { Smigielska-Kuzia } \\
\text { and Sobaniec, } \\
2007\end{array}$ \\
\hline $\begin{array}{l}\text { Smigielska-Kuzia } \\
\text { et al. }\end{array}$ & 2010 & Temporal lobes & $\begin{array}{l}n=20 \text { DS } 3-15 \text { years and } \\
n=20 \text { controls } 6-15 \text { years }\end{array}$ & None & $\begin{array}{l}\text { GIx was not different between the DS } \\
\text { and control groups. NAA and MI was } \\
\text { significantly lower in DS relative to } \\
\text { controls. GABA was also lower in DS. }\end{array}$ & $\begin{array}{l}\text { Smigielska-Kuzia } \\
\text { et al., } 2010\end{array}$ \\
\hline Lamar et al. & 2011 & Hippocampus & $\begin{array}{l}n=35 \text { demented people } \\
\text { with DS (Avg age }=52.8 \\
\text { years), } n=18 \\
\text { non-demented DS (Avg age } \\
47.2 \text { years) and } n=13 \\
\text { controls (Avg age } 50.6 \\
\text { years), } n=39 \text { sporadic AD } \\
\text { (Avg age } 76.8 \text { years) }\end{array}$ & CAMDEX & $\begin{array}{l}\text { MI was significantly higher in DS with } \\
\text { dementia relative to non-demented } \\
\text { DS ( } 13 \% \text { higher) and controls ( } 19 \% \\
\text { higher).NAA was significantly reduced } \\
\text { in DS with dementia relative to DS } \\
\text { without dementia ( } 11 \% \text { ) but was } \\
\text { similar to controls. DS with dementia } \\
\text { MI was significannlty higher relative to } \\
\text { sporadic AD. }\end{array}$ & Lamar et al., 2011 \\
\hline Tan et al. & 2014 & Hippocampus & $\begin{array}{l}n=35 \text { non-demented DS } \\
\text { (Avg age } 35 \text { years), } n=11 \\
\text { demented DS (Avg age } 52 \\
\text { years) and } n=39 \text { controls } \\
\text { (Avg age } 35 \text { years) }\end{array}$ & CAMCOG & $\begin{array}{l}\text { No differences in Glx across the } 3 \\
\text { groups nor correlation with cognition. }\end{array}$ & Tan et al., 2014 \\
\hline Lin et al. & 2016 & $\begin{array}{l}\text { Posterior } \\
\text { Cingulate Cortex }\end{array}$ & $\begin{array}{l}n=22 \text { non-demented DS } \\
\text { (Avg age } 46.7 \text { years), } n=5 \\
\text { demented DS (Avg age } 53.7 \\
\text { years), } n=15 \text { control (Avg } \\
\text { age } 47.8 \text { years) }\end{array}$ & SIB, BPT, DMR & $\begin{array}{l}\text { NAA reduced in DS with dementia } \\
\text { relative to controls and non-demented } \\
\text { DS groups. Ml increased in DS } \\
\text { relative to controls but not further } \\
\text { increased with DS and dementia. } \\
\text { Higher NAA levels associated with } \\
\text { cognition (i.e. better performance } \\
\text { associated with more NAA). }\end{array}$ & Lin et al., 2016 \\
\hline
\end{tabular}

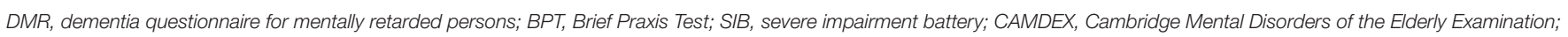
CAMCOG, Cambridge Cognitive Examination. 
increased neuroinflammation that has been observed with aging in DS (Wilcock, 2012).

Thus, MRS provides novel information and unique signatures for DS (e.g., higher MI) but also may be amenable to future treatment studies as metabolic outcomes measured by MRS may be rapidly modifiable as opposed to outcomes reflecting brain structure. Comparing MRS outcomes in different affected brain regions in people with DS (e.g., comparing hippocampus, frontal cortex, cingulate cortex) may provide novel links between the presence of in vivo amyloid by PET imaging and glial/neuronal consequences. For example, as amyloid $\mathrm{PiB}$ binding increases with age, how does NAA or MI decrease or increase correspondingly? These studies may lead us to novel interventions in future for DS with outcome measures and a further examination of the link between MRS outcomes, brain region, and cognition will be useful in future.

\section{VASCULAR IMAGING BIOMARKERS}

Cerebrovascular pathology occurs in over $85 \%$ of autopsy cases presenting with $\mathrm{AD}$ neuropathology and is associated with impaired cognition (Arvanitakis et al., 2016). One form of this pathology, cerebral amyloid angiopathy (CAA) is present in near all brains of people with AD (Viswanathan and Greenberg, 2011). Thus, there is an increasing recognition that along with the development of $A \beta$ plaques and neurofibrillary tangles, vascular neuropathology may also affect cognition and the progression of dementia (White et al., 2002). Interestingly, in DS, there is significant cerebrovascular neuropathology in the form of CAA, primarily due to the overexpression of APP and A $\beta$ (Ikeda et al., 1994; Iwatsubo et al., 1995; Mendel et al., 2010; Head et al., 2017; Zis and Strydom, 2018).

Extensive CAA is associated with microhemorrhages and strokes in general (Arvanitakis et al., 2017; Banerjee et al., 2017) although in DS, stroke is relatively rare (Buss et al., 2016). Nonetheless, CAA may have a significant impact on blood vessel function. CAA can lead to deficits in cerebrovascular regulation (Grinberg et al., 2012) and reduced blood flow may lead to impaired perivascular clearance of $A \beta$. Impaired clearance will in turn lead to additional accumulation of $A \beta$ (Banerjee et al., 2017).

Neuroimaging of CAA is typically by GRE or T2*-weighted MRI (Fazekas et al., 1999). There is only one neuroimaging study using $\mathrm{T}^{*}$ to observe the extent of CAA in vivo in older adults with DS (Carmona-Iragui et al., 2017). CAA was observed in $31 \%$ of cognitively impaired people with DS, which is similar to early onset $\mathrm{AD}(38 \%)$ and higher than sporadic $\mathrm{AD}(12 \%)$. In addition, $15.4 \%$ of people with DS had evidence of intracerebral hemorrhages. Thus, CAA is a consistent feature of aging and dementia in DS and may serve as a future target for clinical trials.

While PET-based studies in DS show metabolic differences that mirror $\mathrm{AD}$ in the general population, changes in blood flow may also be seen in DS. For example, single photon emission computed tomography (SPECT) patterns in younger individuals with DS reveal perfusion changes in temporal, parietal, and occipital regions (Kao et al., 1993) that are also reminiscent of those seen in AD (DeKosky et al., 1990). However, these regional differences in perfusion may reflect the added impact of CAA-associated or other cerebrovascular mechanisms in DS.

Cerebrovascular dysfunction measured in vivo may be critical for understanding not only the aging process and progression to $\mathrm{AD}$ in $\mathrm{DS}$ but treatment that rely on and are also relatively short MR protocols (T2* $\sim 7 \mathrm{~min}$, FLAIR $\sim 4.5 \mathrm{~min}$ ) (Figure 1). Immunotherapy trials in patients with $\mathrm{AD}$ suggest that cerebrovascular adverse effects can occur and are visualized with FLAIR (Sperling et al., 2012). The possibility of a similar outcome in DS is as yet unknown. Intervention studies that target $\mathrm{A} \beta$ or other pathways may be less effective in people with DS with significant cerebrovascular pathology and can confound the opportunity to observe benefits in clinical trials. Characterizing the extent of cerebrovascular pathology may serve as an exclusion/inclusion criteria or included as a covariate so as not to obscure positive clinical outcomes.

\section{DEVELOPMENTAL DIFFERENCES AND CAVEATS WITH NEUROIMAGING IN DS}

Structural differences in childhood and early adulthood suggest that some brain regions (e.g.) are smaller in people with DS whereas others (parahippocampal gyrus) may be larger (Kesslak et al., 1994; Teipel and Hampel, 2006). It will be important to consider additional volumetric tissue losses using structural MRI when interpreting reductions in vascular flow or metabolic outcomes. Additional atrophy occurs with aging in DS and with the development of dementia with posterior cingulate, parietal, temporal, and frontal regions being affected (summarized nicely in Neale et al., 2018).

In studies of people with DS, sample sizes are typically smaller. This is due to challenges with recruitment, the ability of people to be scanned (e.g., fear) or to stay motionless (movement artifacts, people with dementia; Neale et al., 2018). Obesity or being overweight can lead to discomfort in the scanner and in some cases, may preclude a person from participating. The neck and facial structure of people with DS also can lead to discomfort in the prone position. For these situations, there are methods to provide additional padding and support along with frequent pauses in the procedures. Unfortunately, in many studies this leads to small sample sizes of demented individuals with DS, which may skew our results. Anxiolytics can be helpful when obtaining structural images but may interfere with functional measures. In our own experiences, we have found that repeated visits leads to greater successes with our volunteers participating in the scanning procedures and the option of anxiolytics has been helpful. Age of the participant also influences success with scanning. Estimates from our cohort suggest that a full set of images (MPRAGE, FLAIR, T2*, ASL, MRS, DTI $\sim 50 \mathrm{~min}$ ), $92 \%$ of people $25-37$ years, $82 \%$ of $37-50$ year olds and $40 \%$ of 50-65 year olds can be successfully scanned (unpublished observations from the University of Kentucky Down syndrome and Aging study). However, there are fewer sets of full imaging protocols we can acquire with increasing age as our participants may not be able to stay in the scanner as long as we require. 

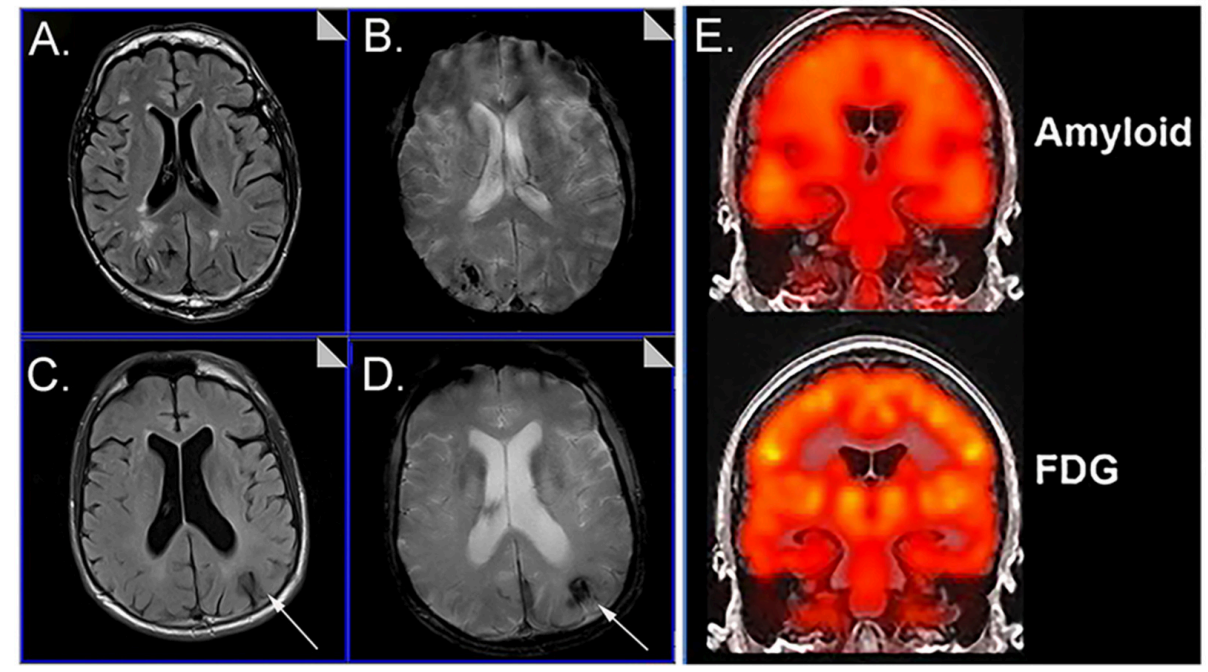

FIGURE 1 | Representative examples of neuroimaging protocols acquired in Down syndrome. Panels (A-D) show MR imaging in a 57 year old male and 59 year old male imaged with T2* (A, C) and FLAIR (B, D) showing the presence of microbleeds. Arrows distinguish edema and hemosiderin positive microbleeds. Panel (E) shows examples of amyloid PiB-PET imaging (top) and FDG-PET imaging (bottom). Images from (A-D) were modified from Figure 5 with permission of Elsevier Press (Head et al., 2018). Images from (E) were modified from Figure 1 reproduced with permission from Dr. M. Rafii and under the Creative Commons Attribution License (CC BY) (Rafii et al., 2015).

\section{SUMMARY AND FUTURE DIRECTIONS}

Longitudinal studies in virtually all of the imaging parameters discussed here are critical. There are few longitudinal studies of metabolic and vascular neuroimaging changes with age in DS. In studies of structural imaging some show progressive atrophy (reviewed in Neale et al., 2018). Over a 3 year period of time, studies in non-demented adults with DS report an increasing number of individuals developing amyloid by PET (PiB binding) and those with existing amyloid binding showed an increasing number of brain regions affected along with increased accumulation within affected brain regions (Hartley et al., 2017; Lao et al., 2017; also reviewed in Neale et al., 2018) (Figure 1). It is interesting to note that $\mathrm{PiB}$ tends to bind more mature amyloid deposits (LeVine et al., 2017) in vitro consistent with the typical age of onset of $\mathrm{PiB}$ binding in DS being after 40 years of age. In summary, neuroimaging is a powerful tool to detect structural, metabolic and vascular changes with age

\section{REFERENCES}

Arvanitakis, Z., Capuano, A. W., Leurgans, S. E., Bennett, D. A., and Schneider, J. A. (2016). Relation of cerebral vessel disease to Alzheimer's disease dementia and cognitive function in elderly people: a cross-sectional study. Lancet Neurol. 15, 934-943. doi: 10.1016/S1474-4422(16)30029-1

Arvanitakis, Z., Capuano, A. W., Leurgans, S. E., Buchman, A. S., Bennett, D. A., and Schneider, J. A. (2017). The relationship of cerebral vessel pathology to brain microinfarcts. Brain Pathol. 27, 77-85. doi: 10.1111/bpa.12365

Azari, N. P., Horwitz, B., Pettigrew, K. D., Grady, C. L., Haxby, J. V., Giacometti, K. R., et al. (1994a). Abnormal pattern of cerebral glucose metabolic rates involving language areas in young adults with Down syndrome. Brain Lang. 46,1-20. doi: 10.1006/brln.1994.1001 and dementia in DS but there are still important gaps in our knowledge remaining. Feasibility concerns may be overcome with the use of mock scanners, increasing sample sizes (based upon estimates of scan success as a function of age and dementia) and reducing scan times. Given that neuroimaging outcomes could be critically important in future clinical trials, it will be important to encourage further studies for people with DS.

\section{AUTHOR CONTRIBUTIONS}

All authors listed have made a substantial, direct, and intellectual contribution to the work, and approved it for publication.

\section{ACKNOWLEDGMENTS}

The authors are supported by NIH/NICHD R01HD064993. The authors thank Dr. M. Rafii for kindly allowing us to reproduce the figure of Amyloid and FDG PET imaging.

Azari, N. P., Pettigrew, K. D., Pietrini, P., Horwitz, B., and Schapiro, M. B. (1994b). Detection of an Alzheimer disease pattern of cerebral metabolism in Down syndrome. Dementia 5, 69-78. doi: 10.1159/000106700

Banerjee, G., Carare, R., Cordonnier, C., Greenberg, S. M., Schneider, J. A., Smith, E. E., et al. (2017). The increasing impact of cerebral amyloid angiopathy: essential new insights for clinical practice. J. Neurol. Neurosurg. Psychiatr. 88, 982-994. doi: 10.1136/jnnp-2016-314697

Beacher, F., Simmons, A., Daly, E., Prasher, V., Adams, C., Margallo-Lana, M. L., et al. (2005). Hippocampal myo-inositol and cognitive ability in adults with Down syndrome: an in vivo proton magnetic resonance spectroscopy study. Arch. Gen. Psychiatry 62, 1360-1365. doi: 10.1001/archpsyc.62.12.1360

Berry, G. T., Mallee, J. J., Kwon, H. M., Rim, J. S., Mulla, W. R., Muenke, M., et al. (1995). The human osmoregulatory $\mathrm{Na}^{+}$/myo-inositol cotransporter gene 
SLC5A3): molecular cloning and localization to chromosome 21. Genomics 25, 507-513. doi: 10.1016/0888-7543(95)80052-N

Berry, G. T., Wang, Z. J., Dreha, S. F., Finucane, B. M., and Zimmerman, R. A. (1999). In vivo brain myo-inositol levels in children with Down syndrome. J. Pediatr. 135, 94-97. doi: 10.1016/S0022-3476(99)70334-3

Bittles, A. H., and Glasson, E. J. (2004). Clinical, social, and ethical implications of changing life expectancy in Down syndrome. Dev. Med. Child Neurol. 46, 282-286. doi: 10.1111/j.1469-8749.2004.tb00483.x

Buss, L., Fisher, E., Hardy, J., Nizetic, D., Groet, J., Pulford, L., et al. (2016). Intracerebral haemorrhage in Down syndrome: protected or predisposed? F1000Res. 5:F1000 Faculty Rev-876. doi: 10.12688/f1000research.7819.1

Carmona-Iragui, M., Balasa, M., Benejam, B., Alcolea, D., Fernández, S., Videla, L. et al. (2017). Cerebral amyloid angiopathy in Down syndrome and sporadic and autosomal-dominant Alzheimer's disease. Alzheimers. Dement. 13, 1251-1260. doi: 10.1016/j.jalz.2017.03.007

Chang, L., Munsaka, S. M., Kraft-Terry, S., and Ernst, T. (2013). Magnetic resonance spectroscopy to assess neuroinflammation and neuropathic pain. J. Neuroimmune Pharmacol. 8, 576-593. doi: 10.1007/s11481-013-9460-х

Cutler, N. R. (1986). Cerebral metabolism as measured with positron emission tomography (PET) and [18F] 2-deoxy-D-glucose: healthy aging, Alzheimer's disease and Down syndrome. Prog. Neuropsychopharmacol. Biol. Psychiatry 10, 309-321. doi: 10.1016/0278-5846(86)90010-2

Dani, A., Pietrini, P., Furey, M. L., McIntosh, A. R., Grady, C. L., Horwitz, B., et al. (1996). Brain cognition and metabolism in Down syndrome adults in association with development of dementia. Neuroreport 7, 2933-2936. doi: 10.1097/00001756-199611250-00026

de Graaf, G., Buckley, F., and Skotko, B. G. (2017). Estimation of the number of people with Down syndrome in the United States. Genet. Med. 19, 439-447. doi: 10.1038/gim.2016.127

DeKosky, S. T., Shih, W. J., Schmitt, F. A., Coupal, J., and Kirkpatrick, C. (1990). Assessing utility of single photon emission computed tomography (SPECT) scan in Alzheimer disease: correlation with cognitive severity. Alzheimer Dis. Assoc. Disord. 4, 14-23. doi: 10.1097/00002093-199040100-00002

Fazekas, F., Kleinert, R., Roob, G., Kleinert, G., Kapeller, P., Schmidt, R., et al. (1999). Histopathologic analysis of foci of signal loss on gradient-echo T2*weighted MR images in patients with spontaneous intracerebral hemorrhage: evidence of microangiopathy-related microbleeds. AJNR Am. J. Neuroradiol. 20, 637-642.

Franceschi, M., Comola, M., Piattoni, F., Gualandri, W., and Canal, N. (1990). Prevalence of dementia in adult patients with trisomy 21. Am. J. Med. Genet. 7, 306-308. doi: 10.1002/ajmg.1320370760

Grinberg, L. T., Korczyn, A. D., and Heinsen, H. (2012). Cerebral amyloid angiopathy impact on endothelium. Exp. Gerontol. 47, 838-842. doi: 10.1016/j.exger.2012.08.005

Haier, R. J., Alkire, M. T., White, N. S., Uncapher, M. R., Head, E., Lott, I. T., et al. (2003). Temporal cortex hypermetabolism in Down syndrome prior to the onset of dementia. Neurology 61, 1673-1679. doi: 10.1212/01.WNL.0000098935.36984.25

Haier, R. J., Head, K., Head, E., and Lott, I. T. (2008). Neuroimaging of individuals with Down's syndrome at-risk for dementia: evidence for possible compensatory events. Neuroimage 39, 1324-1332. doi: 10.1016/j.neuroimage.2007.09.064

Hartley, S. L., Handen, B. L., Devenny, D., Mihaila, I., Hardison, R., Lao, P. J., et al. (2017). Cognitive decline and brain amyloid-beta accumulation across 3 years in adults with Down syndrome. Neurobiol. Aging 58, 68-76. doi: 10.1016/j.neurobiolaging.2017.05.019

Head, E., Helman, A. M., Powell, D., and Schmitt, F. A. (2018). Down syndrome, beta-amyloid and neuroimaging. Free Radic. Biol. Med. 114, 102-109. doi: 10.1016/j.freeradbiomed.2017.09.013

Head, E., Lott, I. T., Hof, P. R., Bouras, C., Su, J. H., Kim, R., et al. (2003). Parallel compensatory and pathological events associated with tau pathology in middle aged individuals with down syndrome. J. Neuropath. Exp. Neurol. 62, 917-926. doi: 10.1093/jnen/62.9.917

Head, E., Lott, I. T., Patterson, D., Doran, E., and Haier, R. J. (2007). Possible compensatory events in adult Down syndrome brain prior to the development of Alzheimer disease neuropathology: targets for nonpharmacological intervention. J. Alzheimers. Dis. 11, 61-76. doi: 10.3233/JAD-2007-11110
Head, E., Lott, I. T., Wilcock, D. M., and Lemere, C. A. (2016). Aging in Down Syndrome and the Development of Alzheimer's Disease Neuropathology. Curr. Alzheimer Res. 13, 18-29. doi: 10.2174/1567205012666151020114607

Head, E., Phelan, M. J., Doran, E., Kim, R. C., Poon, W. W., Schmitt, F. A., et al. (2017). Cerebrovascular pathology in Down syndrome and Alzheimer disease. Acta Neuropathol. Commun. 5:93. doi: 10.1186/s40478-017-0499-4

Head, E., Powell, D., Gold, B. T., and Schmitt, F. A. (2012a). Alzheimer's disease in Down syndrome. Eur. J. Neurodegenerative Dis. 1, 353-364.

Head, E., Silverman, W., Patterson, D., and Lott, I. T. (2012b). Aging and down syndrome. Curr. Gerontol. Geriatr. Res. 2012:412536. doi: 10.1155/2012/412536

Herrera, F., Chen, Q., Fischer, W. H., Maher, P., and Schubert, D. R. (2009). Synaptojanin-1 plays a key role in astrogliogenesis: possible relevance for Down's syndrome. Cell Death Differ. 16, 910-920. doi: 10.1038/cdd.2009.24

Horwitz, B., Schapiro, M. B., Grady, C. L., and Rapoport, S. I. (1990). Cerebral metabolic pattern in young adult Down's syndrome subjects: altered intercorrelations between regional rates of glucose utilization. J. Ment. Defic. Res. 34 (Pt 3), 237-252. doi: 10.1111/j.1365-2788.1990.tb01535.x

Hosking, F. J., Carey, I. M., Shah, S. M., Harris, T., DeWilde, S., Beighton, C., et al. (2016). Mortality among adults with intellectual disability in england: comparisons with the general population. Am. J. Public Health 106, 1483-1490. doi: 10.2105/AJPH.2016.303240

Huang, W., Alexander, G. E., Daly, E. M., Shetty, H. U., Krasuski, J. S., Rapoport, S. I., et al. (1999). High brain myo-inositol levels in the predementia phase of Alzheimer's disease in adults with Down's syndrome: a 1H MRS study. Am. J. Psychiatry 156, 1879-1886.

Ikeda, S., Tokuda, T., Yanagisawa, N., Kametani, F., Ohshima, T., and Allsop, D. (1994). Variability of beta-amyloid protein deposited lesions in Down's syndrome brains. Tohoku J. Exp. Med. 174, 189-198. doi: 10.1620/tjem. 174.189

Iwatsubo, T., Mann, D. M., Odaka, A., Suzuki, N., and Ihara, Y. (1995). Amyloid beta protein (A beta) deposition: a beta $42(43)$ precedes A beta 40 in Down syndrome. Ann. Neurol. 37, 294-299. doi: 10.1002/ana.410370305

Jack, C. R., and Holtzman, D. M. (2013). Biomarker modeling of Alzheimer's disease. Neuron 80, 1347-1358. doi: 10.1016/j.neuron.2013.12.003

Jagust, W., Reed, B., Mungas, D., Ellis, W., and Decarli, C. (2007). What does fluorodeoxyglucose PET imaging add to a clinical diagnosis of dementia? Neurology 69, 871-877. doi: 10.1212/01.wnl.0000269790.05105.16

Kao, C. H., Wang, P. Y., Wang, S. J., Chou, K. T., Hsu, C. Y., Lin, W. Y., et al. (1993). Regional cerebral blood flow of Alzheimer's disease-like pattern in young patients with Down's syndrome detected by $99 \mathrm{Tcm}-\mathrm{HMPAO}$ brain SPECT. Nucl. Med. Commun. 14, 47-51. doi: 10.1097/00006231-199301000-00010

Kesslak, J. P., Nagata, S. F., Lott, I., and Nalcioglu, O. (1994). Magnetic resonance imaging analysis of age-related changes in the brains of individuals with Down's syndrome. Neurology 44, 1039-1045. doi: 10.1212/WNL.44.6.1039

Lamar, M., Foy, C. M., Beacher, F., Daly, E., Poppe, M., Archer, N., et al. (2011). Down syndrome with and without dementia: an in vivo proton magnetic resonance spectroscopy study with implications for Alzheimer's disease. Neuroimage 57, 63-68. doi: 10.1016/j.neuroimage.2011.03.073

Lao, P. J., Handen, B. L., Betthauser, T. J., Mihaila, I., Hartley, S. L., Cohen, A. D., et al. (2018). Alzheimer-Like Pattern of hypometabolism emerges with elevated amyloid-beta burden in down syndrome. J. Alzheimers. Dis. 61, 631-644. doi: $10.3233 / \mathrm{JAD}-170720$

Lao, P. J., Handen, B. L., Betthauser, T. J., Mihaila, I., Hartley, S. L., Cohen, A. D., et al. (2017). Longitudinal changes in amyloid positron emission tomography and volumetric magnetic resonance imaging in the nondemented Down syndrome population. Alzheimer's Dementia 9, 1-9. doi: 10.1016/j.dadm.2017.05.001

Lengyel, Z., Balogh, E., Emri, M., Szikszai, E., Kollar, J., Sikula, J., et al. (2006). Pattern of increased cerebral FDG uptake in down syndrome patients. Pediatr. Neurol. 34, 270-275. doi: 10.1016/j.pediatrneurol.2005.08.035

LeVine, H. 3rd, Spielmann, H. P., Matveev, S., Cauvi, F. M., Murphy, M. P., Beckett, T. L., et al. (2017). Down syndrome: age-dependence of PiB binding in postmortem frontal cortex across the lifespan. Neurobiol. Aging 54, 163-169. doi: 10.1016/j.neurobiolaging.2017.03.005

Lin, A. L., and Rothman, D. L. (2014). What have novel imaging techniques revealed about metabolism in the aging brain? Future Neurol. 9, 341-354. doi: $10.2217 /$ fnl.14.13 
Lin, A. L., Powell, D., Caban-Holt, A., Jicha, G., Robertson, W., Gold, B. T., et al. (2016). ${ }^{1} \mathrm{H}$-MRS metabolites in adults with Down syndrome: effects of dementia. NeuroImage Clin. 11, 728-735. doi: 10.1016/j.nicl.2016.06.001

Lin, A., Ross, B. D., Harris, K., and Wong, W. (2005). Efficacy of proton magnetic resonance spectroscopy in neurological diagnosis and neurotherapeutic decision making. NeuroRx 2, 197-214. doi: 10.1602/neurorx.2.2.197

Matthews, D. C., Lukic, A. S., Andrews, R. D., Marendic, B., Brewer, J., Rissman, R. A., et al. (2016). Dissociation of Down syndrome and Alzheimer's disease effects with imaging. Alzheimers Dement 2, 69-81. doi: 10.1016/j.trci.2016.02.004

Mendel, T., Bertrand, E., Szpak, G. M., Stepien, T., and Wierzba-Bobrowicz, T. (2010). Cerebral amyloid angiopathy as a cause of an extensive brain hemorrhage in adult patient with Down's syndrome - a case report. Folia Neuropathol. 48, 206-211.

Minoshima, S., Giordani, B., Berent, S., Frey, K. A., Foster, N. L., and Kuhl, D. E. (1997). Metabolic reduction in the posterior cingulate cortex in very early Alzheimer's disease. Ann. Neurol. 42, 85-94. doi: 10.1002/ana.410420114

Murata, T., Koshino, Y., Omori, M., Murata, I., Nishio, M., Horie, T., et al. (1993). In vivo proton magnetic resonance spectroscopy study on premature aging in adult Down's syndrome. Biol. Psychiatry 34, 290-297. doi: 10.1016/0006-3223(93)90086-S

Neale, N., Padilla, C., Fonseca, L. M., Holland, T., and Zaman, S. (2018). Neuroimaging and other modalities to assess Alzheimer's disease in Down syndrome. NeuroImage Clin. 17, 263-271. doi: 10.1016/j.nicl.2017.10.022

Ng, N., Flygare Wallen, E., and Ahlstrom, G. (2017). Mortality patterns and risk among older men and women with intellectual disability: a Swedish national retrospective cohort study. BMC Geriatr. 17:269. doi: $10.1186 / \mathrm{s} 12877-017-0665-3$

Parnetti, L., Tarducci, R., Presciutti, O., Lowenthal, D. T., Pippi, M., Palumbo, B., et al. (1997). Proton magnetic resonance spectroscopy can differentiate Alzheimer's disease from normal aging. Mech. Ageing Dev. 97, 9-14. doi: 10.1016/S0047-6374(97)01877-0

Pietrini, P., Dani, A., Furey, M. L., Alexander, G. E., Freo, U., Grady, C. L., et al. (1997). Low glucose metabolism during brain stimulation in older Down's syndrome subjects at risk for Alzheimer's disease prior to dementia. Am. J. Psychiatry 154, 1063-1069. doi: 10.1176/ajp.154.8.1063

Rafii, M. S., Lukic, A. S., Andrews, R. D., Brewer, J., Rissman, R. A., Strother, S. C., et al. (2017). PET Imaging of Tau Pathology and Relationship to Amyloid, Longitudinal, MRI and Cognitive Change in Down Syndrome: results From the Down Syndrome Biomarker Initiative (DSBI). J. Alzheimers Dis. 60, 439-450. doi: 10.3233/JAD-170390

Rafii, M. S., Wishnek, H., Brewer, J. B., Donohue, M. C., Ness, S., Mobley, W. C., et al. (2015). The down syndrome biomarker initiative (DSBI) pilot: proof of concept for deep phenotyping of Alzheimer's disease biomarkers in down syndrome. Front. Behav. Neurosci. 9:239. doi: 10.3389/fnbeh.2015.00239

Sabbagh, M. N., Chen, K., Rogers, J., Fleisher, A. S., Liebsack, C., Bandy, D., et al. (2015). Florbetapir, PET, FDG PET, and MRI in Down syndrome individuals with and without Alzheimer's dementia. Alzheimers Dement 11, 994-1004. doi: 10.1016/j.jalz.2015.01.006

Schapiro, M. B., Azari, N. P., Grady, C. L., Haxby, J. V., and Horwitz, B. (1992a). Down syndrome: differentiating mental retardation and dementia with brain imaging techniques. Prog. Clin. Biol. Res. 379, 103-122.

Schapiro, M. B., Ball, M. J., Grady, C. L., Haxby, J. V., Kaye, J. A., and Rapoport, S. I. (1988). Dementia in Down's syndrome: cerebral glucose utilization, neuropsychological assessment, and neuropathology. Neurology 38, 938-942. doi: 10.1212/WNL.38.6.938

Schapiro, M. B., Grady, C. L., Kumar, A., Herscovitch, P., Haxby, J. V., Moore, A. M., et al. (1990). Regional cerebral glucose metabolism is normal in young adults with Down syndrome. J. Cereb. Blood Flow Metab. 10, 199-206. doi: $10.1038 / \mathrm{jcbfm} .1990 .35$

Schapiro, M. B., Haxby, J. V., and Grady, C. L. (1992b). Nature of mental retardation and dementia in Down syndrome: study with PET, CT, and neuropsychology. Neurobiol. Aging 13, 723-734. doi: 10.1016/0197-4580(92)90096-G

Schupf, N., and Sergievsky, G. H. (2002). Genetic and host factors for dementia in Down's syndrome. Br. J. Psychiatry 180, 405-410. doi: 10.1192/bjp.180.5.405
Schwartz, M., Duara, R., Haxby, J., Grady, C., White, B. J., Kessler, R. M., et al. (1983). Down's syndrome in adults: brain metabolism. Science 221, 781-783. doi: $10.1126 /$ science.6224294

Shonk, T., and Ross, B. D. (1995). Role of increased cerebral myo-inositol in the dementia of Down syndrome. Magn. Reson. Med. 33, 858-861. doi: 10.1002/mrm.1910330619

Silverman, D. H., and Phelps, M. E. (2001). Application of positron emission tomography for evaluation of metabolism and blood flow in human brain: normal development, aging, dementia, and stroke. Mol. Genet. Metab. 74, 128-138. doi: 10.1006/mgme.2001.3236

Silverman, D. H., Small, G. W., Chang, C. Y., Lu, C. S., Kung De Aburto, M. A., Chen, Wm et al. (2001). Positron emission tomography in evaluation of dementia: regional brain metabolism and long-term outcome. JAMA 286, 2120-2127. doi: 10.1001/jama.286.17.2120

Sinai, A., Mokrysz, C., Bernal, J., Bohnen, I., Bonell, S., Courtenay, K., et al. (2018). Predictors of age of diagnosis and survival of Alzheimer's Disease in down syndrome. J. Alzheimers. Dis. 61, 717-728. doi: 10.3233/JAD170624

Smigielska-Kuzia, J., and Sobaniec, W. (2007). Brain metabolic profile obtained by proton magnetic resonance spectroscopy HMRS in children with Down syndrome. Adv. Med. Sci. 52(Suppl. 1), 183-187.

Smigielska-Kuzia, J., Bockowski, L., Sobaniec, W., Kulak, W., and Sendrowski, K. (2010). Amino acid metabolic processes in the temporal lobes assessed by proton magnetic resonance spectroscopy ( ${ }^{1} \mathrm{H}$ MRS) in children with Down syndrome. Pharmacol. Rep. 63, 1070-1077. doi: 10.1016/S1734-1140(10)70369-8

Sperling, R., Salloway, S., Brooks, D. J., Tampieri, D., Barakos, J., Fox, N. C., et al. (2012). Amyloid-related imaging abnormalities in patients with Alzheimer's disease treated with bapineuzumab: a retrospective analysis. Lancet Neurol. 11, 241-249. doi: 10.1016/S1474-4422(12) 70015-7

Tan, G. M., Beacher, F., Daly, E., Horder, J., Prasher, V., Hanney, M. L., et al. (2014). Hippocampal glutamate-glutamine (Glx) in adults with Down syndrome: a preliminary study using in vivo proton magnetic resonance spectroscopy $\left({ }^{1} \mathrm{H}\right.$ MRS). J. Neurodev. Disord. 6:42. doi: 10.1186/1866-1955-6-42

Teipel, S. J., and Hampel, H. (2006). Neuroanatomy of Down syndrome in vivo: a model of preclinical Alzheimer's disease. Behav. Genet. 36, 405-415. doi: 10.1007/s10519-006-9047-x

Viswanathan, A., and Greenberg, S. M. (2011). Cerebral amyloid angiopathy in the elderly. Ann. Neurol. 70, 871-880. doi: 10.1002/ana.22516

White, L., Petrovitch, H., Hardman, J., Nelson, J., Davis, D. G., Ross, G. W., et al. (2002). Cerebrovascular pathology and dementia in autopsied Honolulu-Asia Aging Study participants. Ann. N. Y. Acad. Sci. 977, 9-23. doi: 10.1111/j.1749-6632.2002.tb04794.x

Wilcock, D. M. (2012). Neuroinflammation in the aging down syndrome brain; lessons from Alzheimer's disease. Curr. Gerontol. Geriatr. Res. 2012:170276. doi: $10.1155 / 2012 / 170276$

Zigman, W. B., Schupf, N., Sersen, E., and Silverman, W. (1996). Prevalence of dementia in adults with and without Down syndrome. Am. J. Ment. Retard. $100,403-412$.

Zis, P., and Strydom, A. (2018). Clinical aspects and biomarkers of Alzheimer's disease in Down syndrome. Free Radic. Biol. Med. 114, 3-9. doi: 10.1016/j.freeradbiomed.2017.08.024

Conflict of Interest Statement: The authors declare that the research was conducted in the absence of any commercial or financial relationships that could be construed as a potential conflict of interest.

Copyright (c) 2018 Head, Powell and Schmitt. This is an open-access article distributed under the terms of the Creative Commons Attribution License (CC $B Y)$. The use, distribution or reproduction in other forums is permitted, provided the original author(s) and the copyright owner are credited and that the original publication in this journal is cited, in accordance with accepted academic practice. No use, distribution or reproduction is permitted which does not comply with these terms. 